\title{
PERANAN BRIGADIR JENDERAL SOEHARTO DALAM MEMBANGUN KOMANDO CADANGAN STRATEGIS ANGKATAN DARAT (KOSTRAD) TAHUN 1961 - 1965
}

\author{
Oleh: \\ Cicih Ninawati, Didin Sarifudin, Achmad Iriyadi ${ }^{1}$
}

\begin{abstract}
This research reviews about the role of a character in the formation and development of the Indonesian Republic military organization on the 1961-1965. The background why researcher taking this issue due to the interest in the condition of the development of the Indonesia military organization in the early period of independence. Which is in an all-round hazard and the need for a reliable unit, has forced TNI officer AD to engender a single entity, later called the army General Reserve or CADUAD that no other forerunner of strategic unity and also mobile that right now known as KOSTRAD. The method that used in this research is historical research by doing a four-step research, there are: heuristics, critique, interpretation, and historiography. The results showed that CADUAD is the military organization which was formed and prepared to carry out the operations for the liberation of West Irian that has been delayed since a long time. The establishment of KOSTRAD as one unity of Indonesia's elite military nowadays that is inseparable from the Research Staff Letter filed by Soeharto who is at that time had risen to become a major general. In the years 1961-1965, KOSTRAD has managed to carry out major operations, including Trikora Operation, Dwikora Operation, and operation Completion Problem G $30 \mathrm{~S}$.
\end{abstract}

Keywords: Soeharto, KOSTRAD, The Strategic Unity, Military Operations

\section{PENDAHULUAN}

Permasalahan Irian Barat yang tidak kunjung menemui titik terang telah membawa Pemerintah Indonesia pada keputusan untuk menyelesaikannya dengan langkah yang lebih tegas. Bukti atas hal tersebut adalah munculnya konsepsi yang diucapkan oleh Presiden Soekarno yang kemudian dikenal dengan sebutan Trikora atau Tiga Komando Rakyat dengan isi sebagai berikut:
1. Gagalkan pembentukan Negara Boneka Papua buatan Belanda.

2. Kibarkanlah Sang Merah Putih di Irian Barat Tanah Air Indonesia.

3. Bersiaplah untuk mobilisasi umum mempertahankan kemerdekaan dan kesatuan Tanah Air dan Bangsa (Ridhani, 2009, hlm. 73).

\footnotetext{
${ }^{1}$ Penulis merupakan mahasiswa Pendidikan Sejarah, Fakultas Pendidikan Ilmu Pengetahuan Sosial, Universitas Pendidikan Indonesia, dengan Didin Sarifudin sebagai Dosen Pembimbing 1 dan Achmad Iriyadi sebagai Dosen Pembimbing 2. Untuk kepentingan akademik dapat menghubungi penulis melalui alamat email: cwnina174@gmail.com dan nomor kontak 082315564257
} 
Berdasarkan konsepsi tersebut, jelas bahwa Presiden Soekarno menghendaki pemerintahan Republik Indonesia berdaulat atas wilayah tersebut. Upayayang berusaha dilakukan untuk mencapainya, tersurat dari isi konsepsi nomor tiga yakni mengenai pengerahan mobilisasi umum. Dalam hal ini, mobilisasi umum yang dimaksud adalah penyelesaian melalui upaya pertahanan dan keamanan yang barang tentu memerlukan kesatuan militer untuk menyelesaikannya. Namun, mengingat pada saat itu Indonesia tengah berada pada periode awal kemerdekaan, maka segala sesuatu yang menyangkut sendi kehidupan negara berada pada kondisi yang serba seadanya dan belum tertata dengan baik. Begitupun dengan pengadaan kesatuan militer yang ditegaskan oleh Mardjiono bahwa:

“...sesuai ketetapan Struktur Organisasi dan Tugas Penetapan (TAP) 0-5 yang dikeluarkan pada tanggal 5 Agustus 1958 bahwa setiap wilayah Indonesia dibentuk Komando-komando Daerah Militer (Kodam) yang membawahi Komando Resort Militer(Korem), Kesatuan-kesatuan Brigade, dan Batalyon-batalyon (1993, hlm. 2).

Sehingga, diketahui bahwa kondisi angkatan bersenjata Republik Indonesia masih bersifat territorial dan kedaerahan. Dengan demikian, tugas dan tanggung jawab mereka hanyalah terhadap daerahdaerah yang menjadi wilayah tugasnya masing-masing. Sedangkan untuk permasalahan keamanan yang cakupannya berskala nasional belum ada kesatuan khusus yang memegang dan bertanggung jawab atas hal tersebut. Terlebih lagi, kondisi keamanan dalam negeri selepas perang kemerdekaan pun belum benar- benar pulih. Sehingga, kesatuan-kesatuan yang bersifat territorial tersebut tidak dapat dilibatkan dalam urusan keamanan nasional.

Kondisi tersebut kemudian menimbulkan keresahan Kepala Staf Angkatan Darat (KASAD), Jenderal A. H. Nasution. Beliau mengkhawatirkan kondisi Republik Indonesia sebagai negara yang baru merdeka. Oleh karen itu, beliau mengajukan pentingnya pembentukan kesatuan mobile yang selalu siap tempur dalam keadaan apapun. Maka, pada tahun 1960, beliau mengeluarkan Surat Keputusan No. Kpts-1067/12/1960 mengenai pembentukan CADUAD (Cadangan Umum Angkatan Darat) yang kemudian berganti nama menjadi Komando Cadangan Strategis Angkatan Darat atau lazim disebut KOSTRAD (Mardjiono, 1993, hlm. 5). Tugas utama KOSTRAD tidak lain adalah menjawab setiap ancaman, baik yang berasal dari dalam maupun luar negeri. Tugas tersebut berkaitan dengan pembinaan atas kesiapan operasional segenap jajaran komandonya dalam menyelenggarakan operasi pertahanan tingkat strategis sesuai dengan kebijaksanaan Panglima TNI (Tn, 2009). Di awal pembentukkannya, tenaga kesatuan ini dikerahkan untuk mengatasi sengketa yang terjadi antara Indonesia dan Belanda dalam upaya penyelesaian permasalahan Irian Barat tersebut.

Berangkat dari latar belakang tersebut, penulis memiliki keresahan bagaimana kemudian kesatuan yang baru dibentuk ditugaskan untuk terlibat dalam upaya penyelesaian sengketa yang berskala nasional. Bahkan, pembentukannya pada saat itu pun dilakukan dalam kondisi dan situasi yang serba terdesak. Oleh karena 
itu, Masalah utama yang diangkat dalam skripsi ini adalah "Bagaimana proses pembangunan KOSTRAD sebagai kesatuan siap tempur di bawah kepemimpinan Brigadir Jenderal Soeharto pada tahun 1961 - 1965?”. Kemudian, masalah utama tersebut dijabarkan ke dalam pertanyaan penelitian sebagai berikut; (1) Bagaimana proses pembentukan Komando Cadangan Strategis Angkatan Darat (KOSTRAD) sebagai kesatuan siap tempur?; (2) Bagaimana komando-komando yang dikeluarkan Brigadir Jenderal Soeharto dalam membangun Komando Cadangan Strategis Angkatan Darat (KOSTRAD) pada kurun waktu 1961 - 1965? ; (3) Bagaimana prestasi yang berhasil dicapai Komando Cadangan Strategis Angkata Darat (KOSTRAD) selama masa kepemimpinan Brigadir Jenderal Soeharto?

\section{METODE PENELITIAN}

Dalam penelitian ini, peneliti menggunakan metode penelitian historis dengan langkah-langkah sebagai berikut:

1. Heuristik. Heuristik merupakan upaya mencari dan mengumpulkan sumber-sumber yang berkaitan dengan permasalahan yang dikaji, baik berupa sumber benda, sumber lisan, maupun sumber tertulis. Abdurahman mengemukakan bahwa heuristik adalah suatu keterampilan dalam menemukan, menangani, dan memerinci bibliografi, atau mengklarifikasi dan merawat catatancatatan (2007, hlm. 64). Untuk itu, pada pelaksanaan tahapan ini, peneliti mengunjungi beberapa perpustakaan besar yang tersebar di Provinsi Jawa Barat, diantranya Perpustakaan Universitas Pendidikan Indonesia, Perpustakaan Pusat Angkatan Darat, Dinas Sejarah Angkatan Darat, dan Badan Perpustakaan dan
Kearsipan Daerah Jawa Barat. Berdasarkan pencarian ke perpustakaan-perpustakaan tersebut, penulis berhasil mengumpulkan beberapa sumber utama, baik berupa dokumen maupun buku seperti: dokumen Dharma Bhakti Komando Tempur II/ KOSTRAD "Vira Cakti Yudha", Sejarah Singkat Kopur II/KOSTRAD 15 Januari 1962 - 15 Januari 1970" dan "Sejarah Satuan Divisi I dan Divisi II KOSTRAD" yang berhasil penulis dapatkan dari Dinas Sejarah Angkatan Darat. Dan beberapa buku utama seperti, Militer dan Politik di Indonesia, 32 Tahun Dharma Bakti KOSTRAD Darma Putra 1961 - 1993, Gelora Konfrontasi Mengganyang Malaysia 196, Irian Barat dari Masa ke masa, Politik Luar Negeri, Studi Kasus Penyelesaian Konfrontasi Indonesia - Malaysia, Sejarah TNI - AD 1945 - 1973, dan beberapa buku lainnya.

2. Kritik Sumber. Pada tahapan ini, peneliti melakukan verifikasi untuk menguji validitas sumber-sumber yang telah diperoleh sebagai uapaya penulisan sejarah berkaitan dengan Peranan Brigadir Jenderal Soeharto dalam Membangun KOSTRAD. Tidak semua sumber yang telah diperoleh dari hasil penelusuran relevan digunakan sebagai sumber dalam penelitian ini, baik itu dilihat dari segi otentikitas keaslian sumber ataupun isi dari sumber tersebut. Kritik dilakukan terhadap isi sumber atau dokumen (kritik interen) untuk menguji kredibilitas isi buku menjadi fakta atau yang sudah dianggap kebenaranya. Misalnya dalam beberapa buku terdapat penjelasan berbeda mengenai Operasi Trikora dan keterlibatan KOSTRAD di dalamnya. Oleh karena itu penulis perlu untuk melakukan perbandingan sumber untuk mencari sumber sejarah yang benar-benar relevan. 
Kritik sumber dilakukan untuk mengetahui beberapa fakta mengenai bagaimana latar belakang pembentukan kesatuan KOSTRAD, peran Brigadir Jenderal Soeharto dalam upaya membangun KOSTRAD, dan bagaimana prestasi yang berhasil dicapai oleh KOSTRAD di bawah kepemimpinan Brigadir Jenderal Soeharto.

3. Interpretasi. Setelah melakukan tahapan kritik sumber, tahapan dalam penelitian selanjutnya adalah interpretasi. Dimana, tahapan ini berkaitan dengan kemampuan penulis untuk menganalisis informasi yang berhasil didapatkan untuk kemudian disintesiskan agar menghasilkan suatu interpretasi yang menyeluruh (Kuntowijoyo, 1995, hlm. 73). Sumber-sumber yang telah diperoleh dihubungkan anatara fakta satu sama lain untuk mengetahui sejarah yang berkaitan dengan topik kajian penelitian ini. Untuk selanjutnya dapat direkontruksi menjadi sebuah tulisan sejarah.

4. Historiografi. Tahapan terakhir yang dilakukan peneliti dalam metode penelitian sejarah adalah melaporkan hasil penelitian atau historiografi. Seperti yang diungkapkan oleh Sjamsuddin bahwa historiografi ini merupakan langkah akhir dari keseluruhan prosedur penulisan karya ilmiah sejarah yang merupakan kegiatan intelektual dan cara utama dalam memahami sejarah (2007, hlm. 156). Penulisan skripsi ini menggunakan sistem penulisan yang mengacu pada pedoman penulisan karya tulis ilmiah Universitas Pendidikan Indonesia yang diterbitkan tahun 2015. Hasil penelitian ini kemudian menghasilkan sebuah karya ilmiah yang berjudul Peranan Brigadir Jenderal Soeharto dalam Membangun Komando
Cadangan Strategis Angkatan Darat tahun 1961 - 1965 .

\section{HASIL PENELITIAN DAN PEMBAHASAN}

1. Proses Pembentukan Komando Cadangan Strategis Angkatan Darat (KOSTRAD)

Pembentukan KOSTRAD sebagai salah satu kekuatan militer Indonesia tidak terlepas dari kondisi keamanan dan stabilitas politik yang berkembang pada saat itu. Dimana, menjelang tahun 1961 sejarah mencatat bahwa berkali-kali terjadi ketegangan antara golongan militer dan golongan sipil dalam hal penyelesaian masalah-masalahyangmasihberkelanjutan sejak periode perang kemerdekaan. Muhaimin menyebut hal tersebut sebagai perbedaan strategi dalam menghadapi kekuatan asing yakni berkaitan dengan strategi diplomasi dan strategi perang (1982, hlm. 28). Pemerintah sipil tidak menghendaki penyelesaian permasalahanpermasalahan tersebut dilakukan dengan terburu-buru dan mengandalkan kekuatan fisik, dalam hal ini tentu saja ditujukan untuk golongan militer. Dengan kata lain, golongan sipil tidak menghendaki penyelesaian masalah dengan cara kekerasan karena mereka beranggapan bahwa hal tersebut hanya akan merugikan Bangsa Indonesia. Mengingat, pada saat itu kondisi organisasi militer Indonesia masih terbatas dalam segala hal termasuk dalam bidang persenjataan.

Di lain pihak, pertentangan antara keduanya pun semakin memuncak ketika golongan sipil terlibat dalam urusan militer. Dimana, hal tersebut dilatarbelakangi oleh keputusan pemerintah sipil dalam memilih Kepala Staf Angkatan Darat (KSAD). 
Padahal, peristiwa 17 Oktober 1952 yang berhasil diselesaikan dengan Piagam Yogya di dalamnya disepakati bahwa:

TNI-AD akan berupaya untuk mempertahankan persatuan dan profesionalisme, tidak membenarkan campur tangan politik, dan pengangkatan pada sesuatu jabatan militer harus didasarkan pada senioritas dan kecakapan (Muhaimin, 1982, hlm. 78).

Namun, hal tersebut ternodai oleh pengangkatan Kolonel Bambang Oetojo sebagai Kepala StafAngkatan Darat (KSAD) oleh Iwa Kusumasumantri yang pada saat itu menjabat sebagai Menteri Pertahanan. Selain itu, keterlibatannya pun dipicu oleh seringnya pergantian kabinet yang kemudian memunculkan anggapan bahwa golongan sipil tidak becus dalam mengurus urusan negara.

Pertentangan antara kedua golongan ini kemudian semakin meluas dampaknya manakalaPresidenSoekarnomengeluarkan sebuah konsepsi yang dianggap dapat menyelesaikan permasalahan tersebut. Konsepsi yang dimaksud adalah konsepsi yang dikeluarkan pada tanggal 21 Februari 1957 di hadapan para pemimpin partai dan tokoh masyarakat, isi konsepsi tersebut tidak lain adalah sebagai berikut:

1. Sistem Demokrasi Parlementer secara Barat tidak sesuai dengan kepribadian Indonesia, oleh karena itu harus diganti dengan Sistem Demokrasi Terpimpin.

2. Untuk pelaksanaan Demokrasi Terpimpin perlu dibentuk suatu Kabinet Gotong Royong yang anggota-anggotanya terdiri dari semua partai dan organisasi berdasarkan perimbangan kekuatan yang ada dalam masyarakat. Konsepsi Presiden ini mengetengahkan pula perlunya pembentukan "Kabinet Kaki Empat” yang mengandung arti bahwa empat partai besar, tidak hanya PNI, Masyumi, dan NU, melainkan juga PKI, harus turut serta di dalamnya untuk menciptakan kegotongroyongan nasional.

3. Pembentukan Dewan Nasional yang terdiri dari golongan fungsional dalam masyarakat. Dewan Nasional ini juga tugas utamanya adalah memberi nasihat kepada Kabinet, baik diminta ataupun tidak (Notosusanto, 1991, hlm. 76).

Berdasarkan isi konsepsi tersebut tersirat bahwa Presiden Soekarno menghendaki pembentukan Kabinet Gotong Royong yang merangkul empat partai terkuat di Indonesia yakni PNI, Masyumi, NU, dan PKI. Namun, justru hal tersebutlah yang membawa Indonesia pada krisis keamanan karena sering kali terjadi ketegangan-ketegangan yang tidak saja terjadi di wilayah pusat namun terjadi juga di daerah-daerah. Selain tidak menghendaki konsepsi yang diajukan presiden, tuntutan yang mereka ajukan kepada pemerintah pusat pun mendesak agar Hatta dikembalikan ke dalam fungsi pemerintahan yang dominan.

Melihat kondisi bangsanya yang tidak dalam keadaan baik, Nasution kemudian mengajukan gagasannya kepada Presiden Soekarno untuk mengumumkan berlakunya keadaaan darurat perang di seluruh negeri sebagai langkah pertama ke arah pemulihan persatuan nasional. Soekarno kemudian menyetujui gagasan ini karena beliau tidak memiliki alternatif lain kecuali kembali mengangkat Hatta sebagai wakil presiden dan beliau tidak menghendaki hal tersebut. Berlakunya S. O. B (Staat Oorlog van Beleg) atau keadaan darurat perang ini merupakan 
dasar hukum yang melegitimasi militer untuk melakukan tindakan-tindakan nonmiliter. Secara resmi militer telah memiliki payung hukum untuk mengambil tindakan dan campur tangan dalam urusan politik. Hal ini ditegaskan Sundhaussen bahwa:

Dalam keadaan darurat perang (Staat van Beleg), "pejabat-pejabat militer, dalam mengubah ketentuan-ketentuan peraturan umum, berwenang mengambil tindakan yang bagaimanapun... apabila hal itu mereka anggap perlu mengingat situasi darurat perang yang nyata (1988, hlm. 224).

Dengan demikian, tidak saja bertindak sebagai organisasi yang bertanggung jawab dalam menjaga keamanan, namun setelah diberlakukanya S. O. B, militer menjadi bagian yang paling penting dari administrasi nasional di seluruh Indonesia. Bahkan, Crouch menegaskan bahwa keadaan darurat perang tidak saja memberikan wewenang militer dalam mengeluarkan keputusan berkaitan dengan bidang politik, namun juga menyangkut bidang-bidang administrasi umum dan pengelolaan ekonomi (1986, hlm. 32). Keadaan darurat perang telah memberikan tempat perwakilan kepada para perwira dalam lembaga-lembaga resmi pemerintahan.

Permasalahan politik yang berhasil diredam dan kemudian memunculkan dominasi golongan militer di dalamnya, tidak serta merta menyelesaikan pergolakan dan ketegangan yang terjadi di daerah. Menjelang tahun 1961 situasi keamanan masih tidak stabil. Hal tersebut tidak lain disebabkan oleh ketidakmampuan pemerintah pusat dalam menyelesaikan permasalahan negara secara cepat dan sering terjadinya pergantian kabinet merupakan faktor utama atas ketegangan di daerah tersebut. Terlebih lagi, gelombang protes ini mengkritisi pembangunan ekonomi yang terpusat di perkotaan. Dampaknya, Wilayah Sumatra Barat memproklamasikan Pemerintah Revolusioner Republik Indonesia (PRRI) pada tanggal 15 Februari 1958 oleh Achmad Husein (Notosusanto, 1991, hlm. 85). Gagasan pembentukan pemerintahan revolusioner ini berasal dari Mr. Syafruddin Prawiranegara yang beranggapan bahwa pembentukan PRRI berarti telah mewakili seluruh kekuatan dewan-dewan daerah yang menentang Presiden Soekarno (Djamhari, 2012, hlm. 313).

Walaupun dengan tujuan dan visi misi yang mengatasnamakan Republik Indonesia, namun PRRI-Permesta ini banyak mendapatkan tanggapan keras dari orang-orang yang masih setia kepada Pancasila, Saptamarga, dan Sumpah Prajurit. Mereka adalah orang-orang nasionalis yang menyatakan kesetiaan terhadap NKRI dan menolak dengan keras setiap bentuk usaha pemisahan diri. Sehingga, tidak heran jika beberapa pihak seperti pemerintah dan TNI AD mengupayakan musyawarah sebagai upaya penyelesaian. Namun, golongan separatis menolak dengan keras hal tersebut dan berakibat pada keputusan dari pemerintah dan KSAD untuk menyelesaikan permasalahan tersebut melalui operasi militer (Notosusanto, 1991, hlm. 85). Operasi yang dilakukan merupakan operasi gabungan antara Angkatan Darat, Angkatan Laut, dan Angkata Udara. Dimana, operasi gabungan ini terdiri dari Operasi Saptamarga di Sumatra Utara, Operasi Tegas di Riau, Operasi Sadar di Sumatra Selatan, Operasi Insyaf, Mena, dan Merdeka di Sulawesi 
dan Maluku (Notosusanto, 1991, hlm. 86). Tujuan penyebaran operasi gabungan di berbagai wilayah tersebut ditujukan untuk mengamankan potensi-potensi yang dimiliki setiap daerah, terutama berkaitan dengan potensi Sumber Daya Alam berupa sumber minyak yang tidak lain merupakan sumber kekayaan negara. Berdasarkan pada operasi-operasi yang telah dilaksanakan tersebut, gerakan separatis berhasil dilumpuhkan pada pertengahan tahun 1958. Hal tersebut ditandai dengan mundurnya pasukan PRRI ke pedalaman dan melakukan geriliya yang tidak begitu berarti. Sehingga, secara de facto TNI telah berhasil memegang kekuasaan atas Sumatra yang ditandai dengan berhasil direbutnya Padang pada 17 Apri 1958 dan Bukittinggi pada o5 Mei 1958 (Muhaimin, 1982, hlm. 106).

Berkaca pada kondisi keamanan nasional tersebut, diketahui bahwa Republik Indonesia selalu berada pada kondisi yang tidak tentram. Atas dasar kondisi tersebutlah pimpinan Angkatan Darat merasa perlu membentuk suatu tenaga cadangan sebagai kekuatan militer yang bersifat mobile, siap tempur, dan mampu melaksanakan operasi-operasi gabunganuntukmenyelesaikantugas-tugas nasional (Disjarahad, Tt, hlm. 27). Dengan adanya gagasan mengenai pembentukan kekuataan militer tersebut dan tentu saja setelah melewati pertimbangan yang matang, maka Kepala Staf Angkatan Darat (KSAD) Jenderal A. H. Nasution mengeluarkan Surat Keputusan No: Kpts1067/12/1960 tertanggal 27 Desember 1960 mengenai pembentukan Cadangan Umum Angkatan Darat (CADUAD). Adapun isi dari Surat Keputusan tersebut adalah sebagai berikut:
1. Mempercepat penyusunan CADUAD dan menyelesaikannya menjadi kekuatan yang "siap tempur" pada akhir 1961.

2. Penyusunan CADUAD mendapat prioritas tertinggi dalam perencanaan/ pelaksanaan tahun 1961.

3. Segala ketentuan, alokasi, materiil, keuangan, fasilitas pendidikan dan sebagainya yang telah digariskan/ ditetapkan untuk Kodam-kodam dan badan-badan lainnya, ditinjau kembali untuk disesuaikan dengan prioritas penyusunan CADUAD tersebut di atas.

4. Daftar satuan dan susunan CADUAD serta perencanan dan pelaksanaan penyusunannya diatur sendiri.

5. Surat Keputusan ini berlaku sejak 5 Desember 1960 (Bintal, 2010, hlm. 6).

Kemudian, sebagai tindak lanjut surat keputusan tersebut Jenderal Nasution membentuk kelompok kerja untuk menyusun personalia yang akan mengisi kesatun ini. Maka, pada tanggal 10 April 1961 Jenderal Nasution kembali mengeluarkan Surat Keputusan No. Kpts-295/4/1961 mengenai pengesahan organisasi dan kekuatan Korra I/CADUAD yang didalamnya termasuk satu organisasi infanteri (Disjarahad, Tt, hlm. 28). Dimana, berdasarkan surat keputusan tersebut, berikut susunan staf pejabat umum dari Korra I/CADUAD:

1. Panglima : Brigjen TNI Soeharto

2. Kepala Staf : Kolonel Inf. Akhmad Wiranatakusumah

3. Ass I : Let. Kol. Inf. Joko Basuki

4. Ass II : Let. Kol. Inf. Amir Machmud 
5. Ass III : Let. Kol. Inf. Slamet Soedibyo

6. Ass IV : Let. Kol. Inf. Soenggoro

7. Ass V : Let. Kol. Inf. Moenadi

8. Sekretaris : Pelda Sofjan Nurdin (Pelaksana sementara) digantikan oleh Kapten Cad Soekotjo.

Selanjutnya,JenderalNasutionkembali mengeluarkan Surat Keputusan bernomor: Kpts-342/4/1961 tertanggal 27 April 1961 yang berisi mengenai ketetapan atas adanya Divisi II dalam Korra I CADUAD (Disjarahad, Tt, hlm. 29). Dimana, susunan personil pertama dari Divisi I tersebut adalah sebagai berikut:

1. Panglima Divisi : Kol. Inf. Umar Rukmana

2. Kepala Staf : Let. Kol. Inf. Moenadi

3. Asisten I : Mayor Inf. Ali Moertopo

4. Asisten II : Let. Kol. Inf. Amir Judowinarno

5. Asisten III : Let. Kol. Inf. Soewondo Darsono

6. Asisten IV : Mayor Inf. Soeprapto

7. Asisten V : Mayor Inf. Moekadji

8. Dan. Den. Ma : Lettu Inf. K. Soemarto

9. Sekretaris : Kapten Inf. Soepomo

Selain Divisi II, kekuatan Korra I/ CADUAD pun diisi oleh I Brigade Infanteri 3/Pasukan Parasut atau kemudian disingkat Brigif 3/Para yang memiliki kemampuan dan kekuatan di udara. Satuan ini dipimpin oleh Kolonel Infanteri Wiyogo Suyono dan kepala staf yang dijabat oleh Letnan Kolonel Sukresno (Bintal, 2010, hlm. 11).

2. Komando-komando Brigadir Jenderal Soeharto dalam Membangun KOSTRAD
Dengan tercapainya kesepakatan antara Indonesia dengan Belanda di New York pada tanggal 15 Agustus 1962 menunjukan bahwa permasalahan Irian Barat telah mencapai titik terang. Maka, secara berangsur-angsur kesatuan yang terlibat dalam operasi ini dikembalikan ke kesatuannya masingmasing, terkecuali CADUAD. Dalam hal ini, CADUAD ditugaskan sebagai kontingen Indonesia (Kontindo) dalam Pasukan Keamanan PBB di Irian Barat (Mardjiono, 1993, hlm. 13). Masa konsolidasi tersebut kemudian mengundang keresahan Panglima CADUAD atas keberadaan kesatuan yang dipimpinnya. Soeharto, yang saat itu pangkatnya telah naik menjadi Mayor Jenderal pertanggal 1 Januari 1962 (Roeder, 1969, hlm. 169), memiliki pertanyaan apakah CADUAD harus dipertahankan atau tidak, mengingat kondisi keamanan Indonesia belum sepenuhnya pulih. Selain itu, sesuai dengan rencana pembangunan kekuatan militer Indonesia dan sebagai upaya antisipasi atas ancaman keamanan yang kemungkinan kembali terjadi, maka diperlukan satu kesatuan tempur yang mampu dilibatkan dalam berbagai situasi dan kondisi.

Melalui pola pikir yang logis dan bertolak belakang dari fakta-fakta yang ada tersebut, Mayor Jenderal Soeharto kemudian mengemukakan konsepsi mengenai perlunya pembentukan Komando Cadangan Strategis Angkatan Darat dalam tatanan kekuatan Angkatan Darat Indonesia. Gagasan tersebut kemudian diajukan kepada Menteri Panglima Angkatan Darat dalam sebuah telaahan pada tanggal 1 Desember 1962 yang isinya sebagai berikut:

a. Perlunya diadakan suatu Cadangan Umum Angkatan Darat dengan tugastugas: 
1. Penelitian dan pengembangan.

2. Perencanaan dan pelaksanaan latihan-latihan dan manuver.

3. Merencanakan dan membantu operasi-operasi dalam negeri.

4. Merencanakan dan melaksanakan operasi-operasi terhadap ancaman-ancaman dari luar.

5. Memenuhi commitment internasional.

b. Organisasi Cadangan Umum Angkatan Darat perlu didasarkan untuk memenuhi kebutuhan konsepsi strategis militer dalam bentuk kekuatan nyata, siap siaga, dan mudah dikendalikan. Penyusunannya dilaksanakan secara bertahap dengan tidak melepaskan tujuan pokoknya (Mardjiono, 1993, hlm. 14).

Berkas telaahan staf yang diajukan pada tanggal 1 Desember 1962 tersebut mendapatkan respon positif dari Men/ Pangad. Hal tersebut ditandai dengan dikeluarkannya Surat Keputusan pada tanggal 19 Februari 1963 bernomor Kpts178/2/1963 mengenai penghapusan Korra-I/CADUAD menjadi Komando Cadangan Strategis Angkatan Darat (KOSTRAD). Surat keputusan tersebut disertai dengan lampiran yang menyatakan pertimbangan Men/Pangad mengenai perlunya pembentukan KOSTRAD.

Sejalan dengan penghapusan Korra-I/ CADUAD yang kemudian berganti menjadi KOSTRAD, Divisi II pun mengalami perombakandanperubahannama.Dimana, berdasarkan pada Surat Keputusan Men/ Pangad No.Kpts-1427/11/1963 telah ditetapkan bahwa Divisi II mengalami perombakan dan perubahan nama menjadi Komando Tempur - II yang selanjutnya disebut Kopur - II (Disjarahad, Tt, hlm.
47). Begitupun dengan Brigif-3/Para yang sama-sama mengalami perubahan nama menjadi Komando Tempur Lintas Udara atau kemudian disebut Kopur Linud. Masuknya kesatuan ini menjadi bagian organik administratif dari KOSTRAD sesuai dengan Surat Keputusan nomor KEP-75/1/1964. Dengan demikian, setelah selesainya operasi perebutan Irian Barat, disamping Indonesia memperoleh kemenangan untuk hal tersebut, di sisi lain Indonesia pun memiliki kesatuan militer baru yang siap ditempatkan dalam segala medan dan kondisi. Dimana, pada awal pembentukannya, berikut nama-nama yang mengisi jabatan penting di tubuh organisasi militer KOSTRAD:

Panglima : Mayor Jenderal Soeharto

Kepala Staf : Brigadir Jenderal Achmad Wirahadikusumah

Wakil Kepala Staf : Kolonel Infanteri Soenggoro

Asisten - I : Letnan Kolonel Cpm. N. Tjokropranolo

Asisten - II : Letnan Kolonel Infanteri Wahono

Asisten - III : Letnan Kolonel Infanteri Sroehardojo

Asisten - IV : Letnan Kolonel Infanteri D. Hernomo

Asisten $-\mathrm{V} \quad$ : Letnan Kolonel Infanteri Soedarsono Projomiseno (Bintal, 2010, hlm. 18).

Dengan resminya KOSTRAD sebagai salah satu kekuatan militer Indonesia berarti bahwa segala sesuatunya harus dipersiapkan dan ditentukan sesuai dengan ketentuan-ketentuan organisasi militer termasuk berkaitan dengan pengisian dan pembinaan personil. Dimana, pelaksanaannya dilakukan secara bertahap 
dan personil-personil tersebut sebagian besar diambil dari lulusan-lulusan Sekolah Calon Bintara (Secaba) dari Kodam masing-masing (Disjarahad, Tt, hlm. 31). Kemudian, berkaitan dengan pembinaan personil, Mayor Jenderal Soeharto mengadakan pelatihan bagi prajuritprajuritnya. Hal tersebut didasarkan pada Surat Perintah yang dikeluarkan oleh beliau bernomor Print-247/7/1964 tertanggal 11 Juli 1964 yang kemudian latihan tersebut disebut "Latihan Komando Manggala" yang pelaksanaannya diadakan di sekitar daerah Ciater, Subang dan diikuti oleh kekuatan prajurit berikut ini (Disjarahad, Tt, hlm. 49):

1. Brigade 3/Para KOSTRAD : 28 orang

2. Brigade $2 /$ Brawijaya : 45 orang

3. Brigade 3/Diponegoro : 45 orang

4. Brigade 15/Siliwangi : 44 orang

5. Brigade Kavaleri I/KOSTRAD : 25 orang

6. Brigade Artileri I/KOSTRAD: 61 orang

7. Gugusan Zeni : 34 orang

Latihan yang diikuti oleh 282 orang prajurit tersebut dipimpin secara langsung oleh Panglima Kopur - II, Kolonel Inf. A. Kemal Idris, yang dibantu pula oleh semua unsur Staf Kopur - II dan beberapa Gus KOSTRAD dan Pusdiktif Bandung. Di luar tujuan utama untuk memperbaiki persiapan KOSTRAD dalam operasi selanjutnya, latihan ini pun ditujukan untuk hal-hal berikut ini:

1. Memberikan keseragaman berfikir dan bertindak.

2. Memberikan pengetahuan tambahan yang lebih luas terutama pengetahuan lapangan.

3. Memberikan cara membuat/ mengeluarkan perintah-perintah secara lisan dan tulisan bagi PASI-2
Batalyon dan Brigif guna memperlancar pimpinan komando pasukan di lapangan (Disjarahad, Tt, hlm. 49).

Selain latihan tersebut, sebagai upaya untuk meningkatkan kemampuan tempur pasukannya, KOSTRAD kembali mengadakan latihan guna melatih kemampuan-kemampuan pasukannya dalam bentuk latihan Indoktrinasi wilayah. Latihan tersebut ditujukan untuk melatih kemampuan prajurit dalam usaha membebaskan diri dari tangkapan musuh, kemampuan bertempur khusus di rawarawa dan hutan, serta kemampuan dalam menjaga kelangsungan hidup di daerah operasi militer.

Perhatian lainnya Mayjen Soeharto sebagai Panglima KOSTRAD adalah berkaitan dengan kelengkapan logistik dan perlengkapan perang yang harus dimiliki anggotanya. Dalam urusan ini, Mayjen Soeharto membawahi Badan Peralatan KOSTRAD (Pal KOSTRAD) dan Pembekalan Angkutan KOSTRAD (Bekang KOSTRAD). Keduanya merupakan divisi yang bertugas dalam segala urusan kepentingan KOSTRAD berkaitan dengan pemenuhan kebutuhan akan senjata dan keperluan-keperluan tempur lainnya. Di luar kepentingankepentingan tempur, Mayjen Soeharto pun memberikan kontribusinya terhadap dasar ketentuan Pataka yang kemudian dijadian identitas KOSTRAD hingga hari ini. Dimana, secara keseluruhan Pataka tersebut mengandung makna yang tersirat bahwa warga Korps Tentara KOSTRAD harus selalu memperhatikan nilai-nilai kesatria, keberanian, dan kesucian. Nilai-nilai tersebut ditanamkan agar setiap prajurit yang tergabung di dalam Kesatuan KOSTRAD tidak mengenal putus asa, selalu melihat ke hari depan yang 
gemilang, serta selalu mengupayakan diri agar mencapai titik tujuan yang lebih baik dan mendasarkannya pada keyakinan terhadap Tuhan Yang Maha Esa. Selain itu, hal paling penting yang ingin ditanamkan oleh Pangkostrad terhadap prajuritnya adalah senantiasa menjalin paduan berbagai unsur kejiwaan, meliputi segisegi kebulatan tekad, bersetia kawan, dan bersatu padu untuk menggalang ketekunan bakti bersendikan Pancasila, Sumpah Prajurit, dan Sapta Marga (Bintal, 2010, hlm. 130).

3. Prestasi yang Berhasil Dicapai KOSTRAD di Bawah Komando Brigadir Jenderal Soeharto

Selama kurun waktu $1961-1965$, sejarah mencatat bahwa kesatuan ini telah terlibat dalam operasi-operasi penting dalam rangka mempertahankan kedaulatan Republik Indonesia. Telah disebutkan di awal bahwa tujuan pembentukan kesatuan ini adalah untuk menjalankan misi perebutan kembali Irian Barat dari tangan Belanda. Maka, berdasarkan pada tugas pertamanya tersebut, KOSTRAD atau pada masa itu masih disebut CADUAD telah berhasil menjalankan tugas sekaligus menorehkan prestasi pertamanya. Penunjukkan KOSTRAD sebagai kesatuan yang terlibat dalam operasi ini tertuang dalam Surat Keputusan No. Kpts-251/2/1962 mengenai penunjukkan KORRA-1/ CADUAD sebagai salah satu kekuatan Angkatan Darat dalam mendukung operasi pembebasan. Sedangkan berkaitan dengan pemilihan Panglima Komando Mandala (Pangla), Jenderal A. H. Nasution mempercayakannya kepada Mayjen Soeharto yang juga merangkap sebagai Panglima Angkatan Darat Mandala (Pangadla) yang dituangkan dalam surat keputusan Kpts-162/2/1962 tertanggal 23 Februari 1962 (Bintal, 2010, hlm. 22). Dalam pelaksanaan operasi ini, tugas pokok yang harus dijalankan KOSTRAD adalah sebagai komponen taktis operasional dalam menjalankan perintah dari Pangla. Dimana, secara rinci tugas ADLA dalam operasi ini adalah sebagai berikut:

a. Mengembangkan pasukan dan pangkalan dalam suatu Kawasan Darat.

b. Mempertahankan Daerah Kawasan Darat.

c. Menghadapi penyerahan Irian Barat secara damai.

d. Menyelenggarakan Infiltrasi

e. Menyelenggarakan Eksploitasi (Bintal, 2010, hlm. 25).

Selain berhasil menjalankan tugas operasi pembebasan Irian Barat, sampai tahun 1965 KOSTRAD pun berhasil menjalankan dua operasi lainnya, yakni Operasi Dwikora dan Penyelesaian peristiwa 30 September. Dalam kedua operasi ini, KOSTRAD kembali bertindak sebagai satuan pokok yang kemudian tergabung ke dalam satuan organik. Dalam menjalankan Operasi Dwikora, Komando TempurII(Kopur-II)/KOSTRADbertindak sebagai salah satu pasukan pokok dari komponen Angkatan Darat yang kemudian memiliki nama samaran Komando Satuan Tugas Rencong/Komando TempurII (Kosatgas Rencong/Kopur-II) yang mendapatkan daerah operasi meliputi Sumatra Utara dan Kep. Riau. Penugasan tersebut sesuai dengan Surat Keputusan yang dikeluarkan oleh Meng/Pangad dengan nomor KEP-1030/9/1965. Sebagai kesatuan profesional, Pasukan militer Indonesia telah merencanakan rangkaian operasi yang akan dijalankan dalam upaya konfrontasi ini, diantaranya Operasi 
Inteljen, Operasi Teritorial, Operasi Kantong, Psy war, dan upaya sabotase (Dokumen, Tt, hlm. 2). Berdasarkan rencana operasi tersebut, dalam tahapan pertama pasukan militer Indonesia telah berhasil melakukan operasi intelejen, walapun memang banyak nyawa melayang karena kuatnya basis pertahanan musuh. Dimana, hal tersebut disebabkan oleh kuatnya pengawasan dan telitinya bagian penyelidikan mereka. Sehingga, beberapa Pasukan Indonesia pun ditangkap dan ditawan, termasuk salah satunya adalah Serda M. H. Saleh, Kopda Saiman, dan Praka Machmud (Dokumen, Tt, hlm. 5).

Namun, belum sampai strategi-strategi yang telah disusun dijalankan, Indonesia dikejutkan dengan kondisi keamanan dalam negeri yang ditandai dengan penculikan atas perwira tinggi Angkatan Darat. Penculikan atas ketujuh tokoh Angkatan Darat tersebut dimulai pada pukul 03.00 WIB pada tanggal 1 Oktober 1965 yang kemudian menjelang pagi hari banyak pemblokiran di jalan-jalan menuju ke arah Istana Negara (Nurodin, 2015, hlm. 63). Melihat kondisi Jakarta yang seperti itu, maka seluruh kesatuan $\mathrm{AD}$ yang ada segera mengambil tindakan siaga dan seluruh personil Kodam V/Jaya dikerahkan oleh Panglimanya untuk berpatroli di dalam kota. Sedangkan Mayor Jenderal Soeharto sebagai Panglima KOSTRAD segera melakukan rapat bersama stafstafnya untuk menganalisa keadaan dan perencanaan tindakan yang harus diambil (Disjarahad, 1985, hlm. 148). Maka dari itu, usai melaksanakan rapat yang dilakukan di Markas KOSTRAD, Mayjen Soeharto mulai mengambil tindakan dengan menggerakan pasukannya serta kesatuan-kesatuan yang tidak mendukung G $30 \mathrm{~S}$, termasuk di dalamnya bergabung
RPKAD di bawah kepemimpinan Sarwo Edhie (Nurodin, 2015, hlm. 66). Untuk itu, langkah awal sebagai upaya penyelesaian atas permasalahan ini, Mayjen Soeharto mengambil alih sementara pimpinan atas Angkatan Darat dan membentuk Komando Gabungan dengan RPKAD. Upaya penyelesaian atas peristiwa ini dimulai dengan perebutan kembali kantor berita RRI yang sempat dikuasai oleh simaptisan PKI. Kemudian, secara berturut-turut TNI $\mathrm{AD}$ di bawah komando Mayjen Soeharto dan Sarwo Edhie menguasai kantor Telekomunikasi, memberangus media cetak yang dianggap propokatif, dan berhasil merebut kembali Pangkalan Udara Halim Perdana Kusuma. Selanjutnya, penyelesaian atas permasalahan ini dilakukan secara berkepanjangan dengan dilakukan pembersihan-pembersihan simpatisan PKI yang dianggap sebagai aktor propokatif dalam peristiwa ini.

\section{SIMPULAN}

Berdasarkan pelaksanaan penelitian, hasil yang didapatkan diantaranya adalah Pertama, KOSTRAD yang didirikan pada tahun 1961 merupakan jawaban atas kondisi keamanan Indonesia yang tengah berada pada fase kritis, terlebih lagi tujuan utama pembentukannya berkaitan dengan upaya perebutan kembali Irian Barat dari Belanda. Kedua, berdirinya KOSTRAD sebagai salah satu kesatuan elit militer Indonesia pada hari ini tidak terlepas dari Surat Telaahan Staf yang diajukan oleh Soeharto yang saat itu pangkatnya telah naik menjadi Mayor Jenderal. Dimana, pada tanggal 1 Desember 1962 beliau menyerahkan surat tersebut yang berisi pertimbangan-pertimbangan untuk mempertahankanCADUADsebagaikesatuan strategis Indonesia. Surat tersebut kemudian mendapat tanggapan dari Men/Pangad yang 
ditandaidengan penetapanCADUAD sebagai kesatuan militer Indonesia yang bersifat strategis dan kemudian penamaannya dirubah mejadi KOSTRAD. Sampai tahun 1965, perkembangan-perkembangan yang dialami KOSTRAD tidak terlepas dari kebijakan-kebijakan yang dikeluarkannya sebagai Panglima KOSTRAD. Ketiga, Selama empat tahun sejak 1961 sampai dengan 1965, KOSTRAD telah berubah menjadi kesatuan yang lebih siap dan kompeten untuk menghadapi operasi-operasi militer dalam rangka mempertahankan kedaulatan Republik Indonesia. Tercatat, pada kurun waktu tersebut KOSTRAD telah terlibat dalam operasi-operasi besar, diantaranya Operasi Trikora, Operasi Dwikora, dan Operasi Penyelesaian Permasalahan G 30 S.

\section{DAFTAR PUSTAKA}

Abdurahman, D. (2007). Metodologi Penelitian Sejarah. Jogjakarta: Ar-Ruzz Media. (Halaman 4).

Bintal KOSTRAD. (2010). Sejarah KOSTRAD Darma Putra. Jakarta: LPQ Kemenag RI. (Halaman 11).

Crouch, H. (1999). Militer dan Politik di Indonesia. Jakarta: Pustaka Sinar Harapan. (Halaman 9).

Djamhari, S. A. (2012). Peristiwa PRRIPermesta. Dalam Kementerian Pendidikan dan Kebudayaan Indonesia, Indonesia dalam Arus Sejarah Jilid Pasca Revolusi (hlm. 304 - 325). Jakarta: Ichtiar Baru van Hoeve. (Halaman 9).

Kuntowijoyo. (1995). Pengantar Ilmu Sejarah. Yogyakarta: Benteng Budaya. (Halaman 6).

Mardjiono. dkk. (1993). 32 Tahun Darma Bakti Kostrad Darma Putra 1961 1993. Bandung: Makostrad. (Halaman 2).
Muhaimin, Y. A. (1982). Perkembangan Militer dalam Politik di Indonesia 1945 - 1966. Yogykarta: Gadjah Mada University Press. (Halaman 6).

Notosusanto. dkk. (1991). Pejuang dan Prajurit, Konsepsi dan Implementasi Dwifungsi ABRI. Jakarta: Pustaka Sinar Harapan. (Halaman 7).

Nurodin, A. (2015). Sepak Terjang Sarwo EdhieWibowodalam MenjagaStabilitas Keamanan Nasional Indonesia (1965 1989).(Skripsi).Universitas Pendidikan Indonesia, Bandung. (Halaman 17).

Ridhani, R. (2009). Mayor Jenderal Soeharto: Panglima Komando Mandala Pembebasan Irian Barat. Jakarta: Pustaka Sinar Harapan. (Halaman 2).

Roeder, O. G. (1969). Soeharto dari Pradjurit sampai Presiden. Jakarta: Gunung Agung. (Halaman 12).

Sjamsuddin, H. (2007). Metodologi Sejarah. Yogyakarta: Ombak. (Halaman 6).

Sundhaussen, U. (1988). Politik Militer Indonesia $1945 \quad-1967$ Menuju Dwi Fungsi ABRI. Jakarta: LP3ES. (Halaman 8).

Arsip

Arsip Disjarahad. (Tt). Komando Antar Daerah Kalimantan. Departemen Angkatan Darat: Tidak diterbitkan. (Halaman 17).

Dinas Sejarah Angkatan Darat. (TT). Darma Bakti Komando Tempur II / KOSTRAD "Vira Cakti Yudha", Sejarah Singkat Kopur-II/KOSTRAD 15 Januari 1962 15 Januari 1970. Bandung: Disjarahad. (Halaman 10).

Internet:

Tn. (2009). PROFIL KOSTRAD. [Online]. Tersedia di: http://kostrad.mil.id/ index.php/profil. Diakses pada: 07 September 2016. (Halaman 3). 